\section{Mutation of the Blood-Group Genes}

ThE current theory of the mutation of the blood-group genes postulates the appearance of gene $A$ by mutation in one or more sites in the Europe-Asia land mass, and a similar appearance of gene $B$ in India and in Africa.

There is little doubt that the mutation giving rise to gene $A$ and ipso facto to group $A$, must have been a replacement of, or a change in, gene $R$, but the same certainty does not hold for the mutation of gene $B$. Gene $B$ may have been a replacement, in one form or another, of gene $R$ or of gene $A$ or of both genes. Each of these three possibilities implies a different pre-mutation distribution of the genes in the races concerned.

If gene $R$ alone was susceptible to $B$-mutation, then the pre-mutation frequency of $R$ in a race undergoing this change must have been equal to the sum of the post-mutation frequencies of $R$ and $B$, and the frequency of gene $A$ would be unaltered by the phenomenon.

If gene $A$ alone was susceptible, then the frequency of gene $R$ would be unaffected by the change, and the pre-mutation frequency of $A$ would be equal to the sum of the post-mutation frequencies of genes $A$ and $B$.

If both genes were liable to change, then, had the mutation affected all the susceptible genes, the present frequency of gene $B$ would be 100 per cent, and for less complete changes the effect of the mutation is given by the equation :

$$
A=\frac{a}{1-\bar{b}}
$$

where $\mathrm{A}$ is pre-mutation frequency of gene $A, a$ is post-mutation frequency of gene $A, b$ is post-mutation frequency of gene $B$.

This means that in the Hindu, if $R$ alone were susceptible, the pre-mutation frequency of $A$ must have been $0 \cdot 149$; if $A$ alone were susceptible, this frequency must have been 0.440 ; and if both were susceptible, the frequency of $A$ prior to mutation must have been $0 \cdot 210$.

The fact that there are no races showing gene $B$ without some gene $A$ suggests that the presence of $A$ is a sine qua non to the appearance or mutation of $B$. It follows from this that $B$-mutation was a change in gene $A$ alone.

If this be the case, then the pre- $B$-mutation frequency of $A$ will show a maximum in the centre of the Europe-Asia land mass, as opposed to the minimum in the same place shown by the post- $B$ mutation frequency of $A$. This is an attractive idea, as it would imply a single mutation of gene $A$.

In what races other than the Hindu is there direct evidence of $B$-mutation ? It is generally accepted that there must have been such a change in Africa, but the site of this change is generally considered to have been West Africa, mainly because the Yoruba and the Senegalese show a biochemical index of less than unity. However, these peoples could have obtained their present distribution as a result of the mixing of other races in Africa. The only races having $B$ in Africa about which this cannot be said are the pygmies and the Egyptians. These peoples each show a high proportion of both $A$ and $B$, and could have given rise one to the other, but this seems unlikely on other grounds. They could not have received their gene distributions by the crossings of any other known races, even including the Hindu.
If we accept the conception that $B$-mutation was a change in gene $A$ and not in gene $R$, then the distributions of these races could not have arisen from any extant race or races by mutation, but their pre- $B$-mutation frequency of gene $A$ must have been considerably higher than that shown by any modern races, and in fact, higher than that shown by the pre- $B$-mutation phases of any other people.

This implies one of two possibilities : either there was a mutation of $A$ in Africa, or Africa was invaded by peoples having a very high proportion of $A$. When one bears in mind the extreme bastardization of the modern Bush people, it seems likely that they too, in their purer forms, must have had a similar proportion of $A$. Now did these various peoples, Bush, Pygmy and Egyptian, receive their $A$ from the same source, and was this source an African $A$-mutation, or was it the main mass of mankind ?

Finally, there is a third, and very interesting possibility, namely, that Africa was the site of the main $A$-mutation, and that peoples outside Africa have obtained their $A$ from that continent.

$$
\begin{gathered}
\text { South African Institute } \\
\text { for Medical Research, } \\
\text { Johannesburg. } \\
\text { Aug. 9. }
\end{gathered}
$$

Ronald Elsdon-Dew.

\section{Pleistocene Site in the Malay Peninsula}

IT was to be regretted that until recently no artefacts of Pleistocene age had been found in the Malay Peninsula, and particularly so because of the relationship of the peninsula to the now sunken Sundaland which formerly joined Sumatra, Java and Borneo to the mainland of Asia.

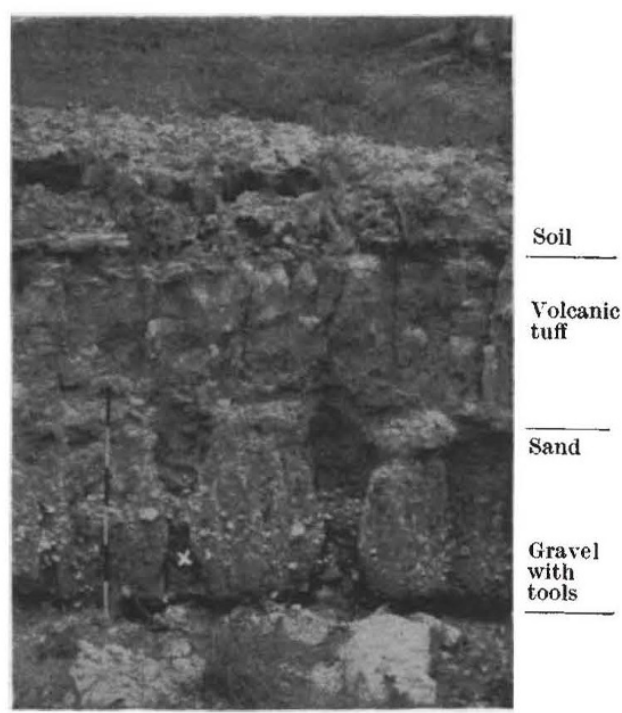

Fig. 1. (Scale in feet.)

Acting on a suggestion of Mr. E. S. Willbourn, director of the Geological Survey, F.M.S., I visited the Kota Tampan Rubber Estate which lies on the west side of the Perak River about three and a half miles south of Lenggong, Upper Perak. On this estate is a deposit of volcanic tuff overlying a bed of sand and gravel which itself rests on laterite. The site lies just below the $250 \mathrm{ft}$. contour and is probably an old terrace of the Perak River. Since there have been no recent volcanoes in Malaya, a foreign origin 